Editorial

\title{
Procedures and Methodologies for the Control and Improvement of Energy-Environmental Quality in Construction
}

\author{
Benedetto Nastasi *(D) and Francesco Mancini (D)
}

Department of Planning, Design and Technology of Architecture, Sapienza University of Rome, Via Flaminia 72, 00196 Rome, Italy; francesco.mancini@uniroma1.it

* Correspondence: benedetto.nastasi@outlook.com

check for updates

Citation: Nastasi, B.; Mancini, F. Procedures and Methodologies for the Control and Improvement of Energy-Environmental Quality in Construction. Energies 2021, 14, 2353. https://doi.org/10.3390/en14092353

Received: 25 January 2021

Accepted: 7 April 2021

Published: 21 April 2021

Publisher's Note: MDPI stays neutral with regard to jurisdictional claims in published maps and institutional affiliations.

Copyright: (c) 2021 by the authors. Licensee MDPI, Basel, Switzerland. This article is an open access article distributed under the terms and conditions of the Creative Commons Attribution (CC BY) license (https:/ / creativecommons.org/licenses/by/ $4.0 /)$.

\section{Overview of the Articles in This Special Issue}

Building performance from an energy and an environmental point of view is fundamental due to the large amount of GHG emissions related to the building sector.

Building retrofitting is aimed at improving such performance to reduce the impact of the building. For this purpose, the Special Issue "Procedures and Methodologies for the Control and Improvement of Energy-Environmental Quality in Construction" has been launched, intended for building technology researchers, building physics experts and urban environment scholars. Among a huge number of submissions, 13 articles were accepted and published.

The first paper published within this Special Issue, authored by Ying et al. [1], deals with the natural ventilation performance in different configurations of yards in office buildings. It found that a higher comfort level corresponds to the multi-yard building type compared to the overall courtyard type. The second paper, authored by Piasecki et al. [2], is about the development of an experimental relation for predicting building users' satisfaction based on the Weber-Fechner law to provide an easy-to-use Indoor Environmental Quality (IEQ) index. The next paper, authored by Piasecki and Kostyrko [3], developed a weighting scheme for the IEQ index accounting for entropy-based and statistic-based approaches. The fourth paper authored by Mancini et al. [4] explored the potential contribution as load flexibility of dwellings in Italy for Demand Response activities, finding out that the most flexible interval is in winter season weekends, accounting for thermal power of Heat Pumps and possible heat storage.

Rosa in [5] investigated the solar energy technologies integrable in historical buildings to increase renewable energy integration by complying with architectural constraints. In [6], Battisti investigates the thermal comfort in open spaces around existing buildings in Rome and the possible improvement thanks to cool materials, greenery and permeable green surfaces. Computational Fluid Dynamics techniques are used in [7] by Gomez et al. to study the fire smoke behavior in an enclosed space, and they present an easy tool to support the design of smoke control systems.

Cieślikiewicz et al. in their study [8] monitored in situ the drying process of masonry walls and recorded the changes in the temperature and moisture as part of the renovation the historical building's basement. Vaisi et al. [9] provided a new thermal energy benchmark for university buildings focusing on monthly resolution in order to improve the accuracy of national action plans and their realization for energy-efficient built environment. In the tenth paper, Grassi et al. [10] investigate how the reduced temperature of a secondgeneration district heating supply can be handled despite the possible occurrence of discomfort caused by the lower output of radiators when working at reduced temperatures. In [11], Cumo et al. present a decision support tool for selecting the best energy retrofitting strategies integrated with a GIS tool for helping planners and Public Administrators.

Persiani et al. [12] authored a review article accounting for the balance between human and built environment resilience by highlighting the role of biomedical signals in indoor 
comfort including the use of stress research. Finally, Bourikas et al. [13] investigated through surveys and experimental measurements the impact of thermal, acoustic and air quality perception in office buildings, finding out that air quality and noise perception affects the thermal sensation.

Author Contributions: Conceptualization, B.N.; writing—original draft preparation, B.N. and F.M.; writing-review and editing, B.N. All authors have read and agreed to the published version of the manuscript.

Funding: This research received no external funding.

Institutional Review Board Statement: Not applicable.

Informed Consent Statement: Not applicable.

Conflicts of Interest: The authors declare no conflict of interest.

\section{References}

1. Ying, X.; Wang, Y.; Li, W.; Liu, Z.; Ding, G. Group Layout Pattern and Outdoor Wind Environment of Enclosed Office Buildings in Hangzhou. Energies 2020, 13, 406. [CrossRef]

2. Piasecki, M.; Kostyrko, K.; Fedorczak-Cisak, M.; Nowak, K. Air Enthalpy as an IAQ Indicator in Hot and Humid EnvironmentExperimental Evaluation. Energies 2020, 13, 1481. [CrossRef]

3. Piasecki, M.; Kostyrko, K. Development of Weighting Scheme for Indoor Air Quality Model Using a Multi-Attribute Decision Making Method. Energies 2020, 13, 3120. [CrossRef]

4. Mancini, F.; Romano, S.; Lo Basso, G.; Cimaglia, J.; de Santoli, L. How the Italian Residential Sector Could Contribute to Load Flexibility in Demand Response Activities: A Methodology for Residential Clustering and Developing a Flexibility Strategy. Energies 2020, 13, 3359. [CrossRef]

5. Rosa, F. Building-Integrated Photovoltaics (BIPV) in Historical Buildings: Opportunities and Constraints. Energies 2020, 13, 3628. [CrossRef]

6. Battisti, A. Bioclimatic Architecture and Urban Morphology. Studies on Intermediate Urban Open Spaces. Energies 2020, 13, 5819. [CrossRef]

7. Gomez, R.S.; Porto, T.R.N.; Magalhães, H.L.F.; Santos, A.C.Q.; Viana, V.H.V.; Gomes, K.C.; Lima, A.G.B. Thermo-Fluid Dynamics Analysis of Fire Smoke Dispersion and Control Strategy in Buildings. Energies 2020, 13, 6000. [CrossRef]

8. Cieślikiewicz, Ł.; Łapka, P.; Mirowski, R. In Situ Monitoring of Drying Process of Masonry Walls. Energies 2020, 13, 6190. [CrossRef]

9. Vaisi, S.; Mohammadi, S.; Nastasi, B.; Javanroodi, K. A New Generation of Thermal Energy Benchmarks for University Buildings. Energies 2020, 13, 6606. [CrossRef]

10. Grassi, B.; Piana, E.A.; Beretta, G.P.; Pilotelli, M. Dynamic Approach to Evaluate the Effect of Reducing District Heating Temperature on Indoor Thermal Comfort. Energies 2021, 14, 25. [CrossRef]

11. Cumo, F.; Giustini, F.; Pennacchia, E.; Romeo, C. Support Decision Tool for Sustainable Energy Requalification the Existing Residential Building Stock. The Case Study of Trevignano Romano. Energies 2021, 14, 74. [CrossRef]

12. Persiani, S.G.L.; Kobas, B.; Koth, S.C.; Auer, T. Biometric Data as Real-Time Measure of Physiological Reactions to Environmental Stimuli in the Built Environment. Energies 2021, 14, 232. [CrossRef]

13. Bourikas, L.; Gauthier, S.; Khor Song En, N.; Xiong, P. Effect of Thermal, Acoustic and Air Quality Perception Interactions on the Comfort and Satisfaction of People in Office Buildings. Energies 2021, 14, 333. [CrossRef] 